\title{
Determinants of Innovation Sustainability on Communication Forum of Land Dispute Resolution: A Case Study of Enrekang Regency
}

\author{
Juanda Nawawi ${ }^{1}$, Asriani Amir ${ }^{2}$, Andi Muhammad Rusli ${ }^{3}$ \\ \{juandanawawi1808@gmail.com¹, asriani.amir17@gmail.com², andirusli2707@gmail.com³ \\ Faculty of Social and Political Sciences, Hasanuddin University, Jl. \\ Perintis Kemerdekaan KM 10, Makassar, 90245, Indonesia
}

\begin{abstract}
The land dispute resolution communication forum is a form of government innovation in the Anggeraja sub-district in accelerating the dispute resolution land. This research aims to examine and analyze the determining factors of sustainability innovation through the implementation of this forum. The study used qualitative descriptive method with data collection techniques through observation, interviews, and documentation. The results showed that several advantages of innovation did not necessarily become a guarantee for an innovation capable of well-adopted. Several factors are considered representative to support and impede the sustainability of innovation. The changes in the typology of disputes and the social characteristics of the community dominated The decisive resistance of innovation in the implementation of the forum. However, the condition is assessed as temporary, considering the dynamic community mobilization and the potential for unpredictable conflicts.
\end{abstract}

Keywords: Land Dispute, Local Governance, Communication Forum, Indonesia

\section{Introduction}

The rolling of regional autonomy brings fundamental changes to local governance. The next effect is the independence of local governments in determining policies and regulations tailored to the urgency of the needs and characteristics of local people [1]. It means that the process of governance is adaptive based on the authority of the area itself. The embodiment of the adaptive process is contained in some local government policies, including Law 23 years 2014, about local government followed up by government regulation number 38 the year 2017 on regional innovation. The goal is to improve governance.

Rogers [2] describes innovation as "an idea, practice, or object perceived as new by the individual or other units of an adopter." Based on that opinion, innovation is an idea, idea, practice, or object that is realized and accepted as a new thing by a person or group to adopt. The defendant also showed that innovation is intangible (intangible) so that its dimensions are very broad. Some of these dimensions are according to [3], among others: incremental innovation, radical innovation, and transformative or systematic innovations. 
One of the incremental innovations conducted by the government of the Anggeraja district is the change of land dispute resolution governance through the strengthening of administrative procedures, verification, and mediation [4] to accelerate land dispute resolution. Innovation in question is the establishment of a land dispute resolution communication Forum which is known as FORSIPENA. This institution is an alternative dispute resolution non-litigation (nonjudiciary) [5], especially the object of dispute that has not been subject to rights or not certified [6]. Its implementation uses a centralized method with the principle of "one case, one action" by minimizing the repetition of the procedure in the old pattern. The goal is to settle the land dispute resolution, which is more effective and efficient, maximally in terms of performance, neat and systematic administratively, and primed in terms of service and is also more easily accountable.

Conceptually, the idea of accelerating land dispute resolution through FORSIPENA can be said to be ideal, evident from some procedural advantages that can provide ease and benefits both to the government as a service provider, as a service user. The contradictions, since the initiation in June 2017, the recorded FORSIPENA only completed 2 (two) cases of land disputes. The numbers are relatively small for innovation with several advantages. Therefore, the study focuses on reviewing the sustainability factor of innovation in the land Dispute resolution communication Forum (FORSIPENA) in Anggeraja District, Enrekang Regency.

\section{Research Method}

The research method used is qualitative with qualitative descriptive research to provide a systematic, factual, and accurate representation of the facts related to the scrutinized matters. This research location is Anggeraja District, Enrekang Regency, from April to June 2019. Data obtained from the informant specified in Purposive, among them the government of both the district government, the District government, and the village/Kelurahan government, the Army/police force, also the community service users. Data collection through interviews, observations, and documentation related to FORSIPENA sustainability.

The data obtained is analyzed descriptively using qualitative techniques by carefully abstracting each information through data reduction, data rendering, and concluding to illustrate the determining innovation sustainability of FORSIPENA in accelerating land dispute resolution. Data validity checks by comparing interviews with the contents of the document also comparing the observation data with the interview result data.

\section{Results and Discussion}

According to Metcalve [7], innovation is a system that compiled different institutions that contributed jointly or individually, in the development and diffusion of new technologies and providing frameworks where governments form and implement policies to influence the 
innovation process. The district has a strategic position and plays a functional role in the service of government administration, development, and the public [8] so that the government of Anggeraja district, as part of government organizations [9], has the authority to determine or taking policies to conduct governance within its territory.

Considering the social culture of the people of Anggeraja district in general, the District government sees the need for innovations in the method of resolving land dispute cases. Technical Instructions for implementation are summarized in the decree of Camat Anggeraja number 08 years 2017 about the establishment of the Communication Forum of Land Dispute Resolution (FORSIPENA) Anggeraja District, on 20 June 2017. The essence of change in the decision letter of the head lies in the improvement of land dispute resolution mechanisms, focusing on pruning repetitive procedures by strengthening the governance by centralized methods. Develop a method of mediation as an alternative dispute resolution non-litigation (non-judiciary) disputes with the concept of community-based land dispute resolution. FORSIPENA is a combination of the number of stakeholders divided into 3 (three) teams, namely administrators, verifications, and mediators, with their respective duties, functions, and responsibilities.

In its development, several sustainability factors always faced every innovation. So does FORSIPENA. Some of them are contributing factors to the success of innovation; some of them become barriers or resistance in innovation. The findings in the field show - since formed in June 2017, FORSIPENA as a new means in resolving land disputes was used only as much as 2 (two) times in dispute resolution cases. Conventional methods resolve some other cases. Ample study suggests dualism of the use of land dispute resolution methods is inevitable, due to the specificity factor of each land dispute typology. Servings, conventional methods tend to be more widely used. While FORSIPENA itself experiences shifting function, a more active complaint hotline is functioning as a means of information and consultation of land problems.

It indicates that there is a problem in the sustainability of FORSIPENA as a government innovation Anggeraja district to accelerate land dispute resolution. The results of data search (interviews, observations, and documentation) on the implementation of FORSIPENA show that several factors are influencing, both supportive and inhibited.

\subsection{Supporting Factors in Implementing FORSIPENA}

The sustainability of innovation depends largely on the factors that support FORSIPENA implementation [10], including:

1. Leadership

The success of an innovation is closely related to the capability of a leader, namely Camat Anggeraja, who can read the community's needs for fast, systematic, and integrated land dispute resolution services. The high phenomenon of the dispute is assessed to potentially interfere with the implementation of the Community's economic activities, so the head of Anggeraja district assesses the need for strengthening governance of the old pattern in settlement of land disputes. Conducted through an innovative approach by forming a land dispute resolution communication 
Forum (FORSIPENA) The adaptive effort synergizes with the vision and mission of the Enrekang Regency to realize good governance

2. Partnership and community empowering

FORSIPENA implementation emphasizes aspects of partnership and community empowerment. Partnership and community empowerment in question here are the involvement of some stakeholders in both internal sub-district to villages/Kelurahan and external stakeholders such as TNI/police, community leaders, religious figures, farmer groups, and others in settlement of land disputes. The involvement of some stakeholders is then legitimate in the form of integrity pact and information on the agreement according to his whistle. The District government's actions are assessed precisely, so the dispute resolution efforts are more directed, the potential disputes between the two parties to the dispute can be minimized so that the security and order of society are maintained.

3. Clear technical indicators

For innovation to thrive on the right track, clear instructions regarding implementation techniques are needed. Starting from the implementation procedure, the individual involved, the clarity of tasks and functions, facilities and complementary infrastructure, and so on. In FORSIPENA, technical instruction is fully described in the decree of Camat Anggeraja number 8 years 2017 about the establishment of the land Dispute resolution communication Forum (FORSIPENA). Appendix I contains the arrangement of the FORSIPENA and appendix II boards containing the fundamentals of FORSIPENA, principal tasks, and management functions, the governance of dispute resolution through FORSIPENA, including several fieldlist formats that each team responsibilities. With the obvious nomenclature, the implementation of FORSIPENA is more structured and neat.

\subsection{Inhibitory Factor in Implementing FORSIPENA}

Innovation is not always happening seamlessly or without resistance. FORSIPENA implementation is generally faced with:

1. Technical Barriers

(a) Dependency reporting complaints via a hotline on the signal provider, whereas it is important to record all information clearly at the time of reporting because later, the preliminary information is the reference for the verification team in conducting the examination Data and facts. When the information is incomplete, it can inhibit the development of subsequent information.

(b) The infrastructure is not complete yet. It is necessary to focus on organizing the activities more directed.

(c) Topographical complicating the verification team reaches the disputed territory,

(d) or the technical skill of the mediator in mediating both parties, also the implementation of socialization is less reach the community completely.

2. Beyond that, the success of implementation relies heavily on non-technical barriers sourced from the community. 
The sustainability of FORSIPENA in Anggeraja district has been stunted to change the typology of disputes and social characteristics of society. Formerly the dispute typology is generally a dispute over the land boundary, then shifted to the heir dispute. The community considers the former typology very precise to use FORSIPENA with the consideration of a faster mechanism and mediated directly at the district level involving many competent parties. Unlike the heir dispute, the community prefers the old pattern in resolving land disputes with the consideration that the old pattern allows settlement of land disputes without having to involve many parties. The authors ' search results indicate that there is a tendency for people to "conceal" the fact that the land rights disputes are among family members, to keep the prestige of the family from the bad assumption surrounding communities.

The "character" factor causes the old pattern in resolving land disputes with conventional methods that can not be eliminated. Both conventional and FORSIPENA methods remain in use. Servings, conventional methods tend to be used more frequently, whereas FORSIPENA itself experiences shifting functions. Currently, the active function of FORSIPENA is a complaint hotline. Usually, people use the service as a means of information and consultation on land issues.

The author assesses the dualism of the land dispute resolution method as the implications of the influence of the typology of disputes and the wishes of the community, indicating the organizational weakness of management functions. If the government wants to enforce the FORSIPENA completely, there must be a determination of the use of dispute resolution methods. The "firmness" in question is a clear foundation of law in the form of Local regulations/ Rule of Regent. Its innovation Model can be revised, adapted, and refined to allow for the settlement of land disputes with any form of the dispute of any kind, including answering the sustainability barriers of innovation from community characteristics.

The adjustments in question could be by creating special procedures in the FORSIPENA based on the potential dispute typologies occurring in the community. For example, for the typology of the heir dispute, so as not to contradict the tendency of society that "keep the shame/prestige of the family" by hiding the facts among the family members are litigants, it can be done with the restrictions of the people Particular to the government apparatus in the area of the dispute object in question. The mediation process can be done in village/Kelurahan, not necessarily in the sub-district. Thus, the FORSPENA post in the district could be a holding post with "branch posts" in each village/Kelurahan. Physically between the parent posts and branch posts may be separate, but the nomenclature remains integrated into a single container, namely FORSIPENA.

Further adjustments are also required, especially in socialization. A slick concept of innovation, without the distribution of information to the community, has a huge impact on the sustainability of innovation. In a dynamic society with continuous economic mobilization, the potential dispute is unpredictable. By that time, Anggeraja district should start to take a persuasive approach to the local government for this innovation to be lifted and enforced throughout Enrekang Regency area, considering FORSIPENA considered very effective in terms of times In the effort to accelerate land dispute resolution. The final goal 
remains on the strengthening of regulation in the form of regional regulations or regent rules. It is important if the goal is sustainability innovation.

\section{Conclusion}

Innovation does not necessarily run smoothly without resistance. Several factors become a defining and successful implementation. Communication Forum of land dispute Resolution (FORSIPENA) as a form of innovation of Anggeraja district government to accelerate land dispute resolution also experienced such. Conceptually, the implementation is judged to be systematic, fast and integrated, supported by leadership factors (partnership) and community empowerment and clear technical indicators. It does not necessarily make FORSIPENA welladopted.

Technically, its sustainability is constrained by inadequate infrastructure, lack of socialization, and the capability of mediators while the non-technical factors are of great effects, such as changes in the typology of disputes and social characteristics of society. The existence of dualism use of land dispute resolution methods indicates the organizational weakness of management functions. If the government wants to enforce the FORSIPENA completely, there should be a determination of the method in resolving disputes. The "firmness" in question is a clear legal basis in the form of Perda/conversation. It's important to expand the sustainability of innovation.

\section{References}

[1] Ndraha. T Ilmu Pemerintahan (Kybernologi), Jakarta. Rineka Cipta (1997)

[2] Rogers E. M. Diffusion on Innovation. Five Edition. New York. The Free Press (2003)

[3] Muluk K.: Knowladge Management: Kunci Sukses Inovasi Pemerintah Daerah, Malang. FIA UNIBRAW (2008)

[4] Maria.S.W. Sumardjono.: Mediasi Sengketa Tanah, Jakarta. PT. Kompas Media Nusantara (2008)

[5] Hadimulyo: Mempertimbangkan ADR. Kajian Alternatif Penyelesaian Sengketa di Luar Peradilan, Jakarta EISAM (1997)

[6] Mu'adi.: Penyelesaian Sengketa Hak atas Tanah Perkebunan dengan Cara Litigasi dan Non Litigasi, Jakarta: Prestasi Pustakarya (2010)

[7] E. Z.: Kepemimpinan Transformatif dalam Inovasi Pemerintah di Pemerintahan Kota Yogyakarta di Era Herry Zudianto (2012)

[8] Sadu Wasistiono, Ismail Nurdin, dan M. Fachrurozi.: Perkembangan organisasi kecamatan dari masa ke masa, Bandung. Fokus media (2009)

[9] Sumaryadi. I. N.: Sosiologi Pemerintahan; Dari Perspektif Pelayanan, Pemberdayaan, Interaksi dan Sistem Kepemimpinan Pemerintahan di Indonesia,Bogor Ghalia Indonesia (2010)

[10] Amir.: Inovasi Pemerintahan Daerah (Studi Percepatan Penyelesaian Sengketa Tanah Berbasis Masyarakat di Kecamatan Anggeraja, Kabupaten Enrekang)", Makassar, Indonesia (2019) 